\title{
The Challenge of Terrorism to Free Societies in the Global Village ${ }^{*}$
}

\author{
Paul Leighton \\ Eastern Michigan University
}

\begin{abstract}
After Sept 11, 110 Nobel laureates released a statement saying "The only hope for the future lies in cooperative international action, legitimized by democracy... To survive in the world we have transformed, we must learn to think in a new way". This chapter argues for criminologists contributing and thinking in a new way by returning to and updating the notion of The Challenge of Crime in A Free Society. It reviews present challenges from terrorism and criminology's shortcomings, explores implications of the new conception, and highlights difficulties in studying anti-American terrorism as well as continued attention to domestic terrorism.
\end{abstract}

\footnotetext{
* Suggested citation: Leighton, Paul. 2004. The Challenge of Terrorism to Free Societies in the Global Village. In Mathieu Deflem (ed), Terrorism and Counter-Terrorism: Criminological Perspectives. Elsevier Science. Available, http://stopviolence.com > Sept 11 Contents.
} 


\section{Introduction}

The FBI's Uniform Crime Reports (FBI 2002a) for 2001 registered an increase in homicides of $2.5 \%$, notable as an end to the decade long drop in crime rates just as criminology produced the first book on the topic (Blumstein and Wallman 2000). Interesting in their absence are all the victims of September 11 terrorism from the categories of murder, assault and hate crimes. While airplane-into-skyscraper is not what comes to mind when thinking about the 'crime problem,' mass murder is still murder - and the UCR has 'explosion' as a subcategory of homicide that has even been used for past terrorism victims.

Excluding 9-11 victims is not based on uncertainty as to how many deaths occurred: for New York, the FBI notes there are 2,830 homicides and 7,233 aggravated assaults that it didn't count. The assaults are excluded because of a "Hierarchy Rule of Summary" which requires that "only the most serious offense in an incident is reported" (FBI 2002b: 7). The homicides are then excluded "because they are statistical outliers that will affect current and future crime trends" and "they are different from the day-today crimes committed in this country" (FBI 2002a: 303). So, the all important 'trend data' - used for reports, articles and textbooks - excludes victims of Sept 11 terrorism, who are relegated to special section of the UCR. However, the UCR will not contain a special section for sniper killings around Washington, D.C. in the fall of 2002, which were not 'day to day crimes'; although the Olympics are held every four years and rotate countries, there was no special section for Eric Robert Rudolph, bomber of the 1996 games in Atlanta. While serial killers frequently populate the media, their victims are 
still infrequent enough to pose the question of why their victimization (such as those cannibalized by John Wayne Gacey) is accepted as 'day to day' crime.

The six victims of the first World Trade Center bombing were included in that year's UCR without comment. But Ramzi Yousef, one of those ultimately convicted, wanted to kill 250,000: "Yousef would explain [it was] the number killed by the American atomic bombs dropped on Hiroshima and Nagasaki. If he could murder on that scale, he believed, he would teach the United States it was in a war" (Benjamin and Simon 2002: 7). His plan was to cause an explosion that would make one tower fall and knock over the other one. While the ultimate damage was not on the order Yousef expected, six deaths, more than a thousand injured, and $\$ 500$ million in damage - "the worst terrorist act" in the nation's history, according to prosecutors (Kittrie and Wedlock 1998: 761) - is not day to day crime.

Further, the 168 victims of Oklahoma City bomber Timothy McVeigh are included in the UCR, with a note in the state data to explain the dramatic increase in Oklahoma's homicide rate (FBI 1996: 64, 78). McVeigh was an enthusiastic reader of the Turner Diaries (MacDonald 1978), a fictional account of Earl Turner's resistance to the 'Zionist Occupied Government' that had overtaken the U.S. and was mistreating white citizens, including through disarming them. Turner starts by passing out leaflets, but by the novel's end becomes a suicide terrorist flying an aircraft loaded with a nuclear weapon in a morning mission to the Pentagon. McVeigh did not have the resources of his fictional hero, but his revenge for the government's killing of citizens at the Branch Davidian compound in Waco (Hamm 1997) was the "deadliest terrorist attack in United States history" (Kittrie and Wedlock 1998: 776). The incident is not day to day crime, but 
the UCR's Index Crime section recorded that murder by explosion increased from 10 in 1994 to 190 in 1995 (FBI 1996: 18).

The attacks of 9-11 are larger in scale, but it hardly makes sense for the UCR to include relatively smaller acts of terrorism when they are the 'worst in history,' and exclude larger ones. According to the FBI, the UCR's "primary objective is to provide a reliable set of criminal justice statistics for law enforcement administration, operation and management" (2002: 2). If so, then it should show what criminal justice professionals already know - that Sept 11 changed their mission and jobs. The FBI now has agents at 46 locations around the world, and "plans to open offices in Kabul, Jakarta and eight other foreign capitals as part of a decade long overseas expansion that officials say is crucial to meet the global threat of al-Qaida and other terrorist groups" (Anderson 2003). The UCR notes its 70 year history is based on "law enforcement agencies voluntarily reporting crimes that were a product of society of the time. However, that society has evolved into a more complex, global society of the twenty-first century that is faced with fighting crimes that previously had been unimaginable" (FBI 2001: 302). The FBI may be opening field offices in Uzbeckistan, Afghanistan, Malaysia and Yemen, but rather than also updating this important statistical reference, the FBI clearly thinks that it is better for the UCR and the mindset of all who depend it on it for information, to be firmly grounded in a simpler era not concerned with global terrorism.

Adding in all the World Trade Center victims of 9-11 does add an outlier to crime data, creating difficulties in analyzing issues like the impact of community policing on violent crime. But since the number of Sept 11 victims is known exactly, individual 
researchers can 'correct' for the impact of terrorism after justifying to themselves and the readers that it is necessary to make the research more 'meaningful.' Such data correction will be legitimate for many projects, but there is value in the making the researcher justify removing it and in the process be introspective about the continued significance of the research question in light of 'unimaginable' new crimes. By including the 9-11 victims, people using the UCR would have a visual reminder of the event because the spike in the homicide graph becomes a memorial - a simple and odd memorial, but one which has great power to engage the thoughts of anyone reading official publications and their derivatives about the nation's 'crime problem.'

Remembering 9-11 would be a regular occurrence exerting an ongoing push on the discipline. Instead, the UCR sets up a model for criminology that continues its disciplinary status quo, which is a "grudging acceptance of terrorism" (Rosenfeld 2002: $1)$.

The problems with not conceptualizing terrorism as crime ultimately go beyond consistency or integrity with the UCR, or even the effects on criminology. Acknowledging the tragic events as crime would require more emphasis on criminal procedure and individual rights enshrined by the Constitution. Negating September 11 victims from 'day to day' crime signals that they are outside traditional notions of a rule of law and supports Presidential assertions about the propriety of unprecedented power; it becomes easier for the administration to set up what have been called 'legal black holes' like Camp X-Ray at Guantanamo Bay where the detainees (including several children) are not recognized as criminal defendants or Prisoners of War. Excluding 9-11 victims undercuts the growing need to further develop international law and stronger 
institutions of international justice for a shrinking global village. Three decades of wars on crime and drugs have already eroded many procedural safeguards important to a democratic society, and the war on terrorism has created further shortcuts in the freedoms that the U.S. is allegedly trying to protect. This is important not just to those whose rights are immediately affected, but also because - contrary to the facile notion that the terrorists 'hate us because we're free' - the Pew Center's Global Attitudes project found "a pattern of support for democratic principles combined with the perception that their nation is currently lacking in these areas is characteristic of many Muslim nations" (Pew Center 2003: 40). Thus, championing democracy in deeds as well as rhetoric is crucial both to preserving the core values of the nation and to U.S. moral leadership in the world.

When the Directors of the Bulletin of the Atomic Scientists moved the hands of its "Doomsday Clock" from nine to seven minutes before midnight, they noted the terrorist acts should have been a global wake-up call: "Moving the clock's hands at this time reflects our growing concern that the international community has hit the 'snooze' button rather than respond to the alarm." The Board went on to "fully support" this warning signed by 110 Nobel laureates: "The only hope for the future lies in cooperative international action, legitimized by democracy...To survive in the world we have transformed, we must learn to think in a new way" (Atomic Scientists 2002). However, since that time, the U.S. pursued a unilateralist war on Iraq, unsupported by the United Nations and without meaningful international cooperation. Disturbingly, the Pew Center found that America has lost much of the goodwill it gained after the attacks of 9-11: "The bottom has fallen out of support for America in most of the Muslim world" (2003: 3). 
In the face of this dire situation, the question is, Can criminology can be a constructive influence for thinking in cooperative, democratic and new ways? Will the discipline instead follow the UCR in keeping the pre-9-11 mentality with its implicit repudiation of the rule of law? If criminologists can overcome disciplinary inertia, what could they contribute?

This chapter argues that criminology can and should make a contribution to the pressing problem of terrorism and in doing so make long overdue disciplinary changes by becoming more global and as interested in topics like ethnic cleansing as serial killers. However, the criminal justice system has spent three decades fighting wars on crime and drugs - efforts that at best have been marginally successful despite enormous expense, and have increased racial tension because of disproportionate minority involvement with the criminal justice system. A War on Terrorism that follows the model of the War on Crime and War on Drugs would be catastrophic.

In order to overcome problems associated with the 'law and order' perspective guiding the destructive War on Crime, this chapter argues for embracing a new guiding framework based on a return to - and update of - The Challenge of Crime In A Free Society (Report by the President's Commission on Law Enforcement and Administration of Justice 1967). The argument is not for a literal rereading of the report, but for criminologists to develop research agendas around the Challenge of Terrorism to the Free Societies of the Global Village. This conception is consistent with statements by the Atomic Scientists and Nobel Laureates; it helps criminology be relevant to the problems of the complex $21^{\text {st }}$ Century global village and will equip students with an understanding of democratic freedoms rather than knee-jerk patriotism. The first section 
below elaborates on the depth of the current challenge from terrorism, antiAmericanism, and the inadequacies of contemporary criminology. The subsequent section explores the new 'paradigm' and its implications for research agendas. The final section provides a preliminary discussion of the challenges posed by studying antiAmericanism, the limits of understanding it, and the importance of not creating "Islamicterrorist" to go with the "criminalblackman" (Russell 1998) bogeyman.

\section{The Challenge}

Emphasis on the free society is not meant to minimize the threat posed by terrorists or anti-Americanism. Al Qaida has been disrupted, but the string of bombings so far in 2003 show it is still a potent force'. President Bush declared after Sept 11 that he wanted mastermind Osama bin Laden "dead or alive," but attention shifted to Iraq and on the second anniversary of 9-11, observers wryly comment 'Osama bin Forgotten.' Less humorously, the war in Iraq 'widened the rift between Americans and Western Europeans, further inflamed the Muslim world, softened support for the war on terrorism, and significantly weakened global support for the pillars of the post-World War II era - the U.N. and the North Atlantic alliance" (Pew Center 2003: 1).

Even without the war on Iraq, the problems raised by September 11 are formidable. The global village - "a stepchild of technology, not the flowering of community" (Johnson 2001) - gets smaller. Issues of oil, geo-politics, deeply ambivalent reactions to hegemonic American culture, along with a variety of other factors, play into terrorism; and a failure to understand the root causes of terrorism guarantees its perpetuation. Conflicts with parts of the Muslim population are likely for the near future 
and "top Bush aides have begun to talk about a long and expensive U.S. presence in the Middle East, a generational commitment akin to the half-century presence in Europe during the Cold War" (Milbank and Allen 2003: A01). On the eve of the second anniversary of 9-11, a video of bin Laden has surfaced, in which his top deputy says the United States has so far experienced "just the first skirmishes" and "the real battle has not started yet. Prepare yourself for the punishment for your crimes" (CNN 2003).

Sadly, even after the 9-11 crisis, American interest in foreign news is low, with the number who follow international news 'somewhat closely' unchanged from before 911. The "modest increase" in those who follow foreign news 'very closely' "comes from the ranks of those who are already interested in international news" (Kutz 2002: A13). In spite of low interest in information about the world, Americans are willing to back extreme measures to the fight the war on terror: "one in 3 could accept governmentsanctioned torture of suspects" and "27 percent could support using nuclear weapons, compared with just 10 percent for use of chemical or biological weapons - even though nuclear weapons are typically far more destructive" (McLaughlin 2001). [Readers who have forgotten why Yousef was bombing the trade center the first time should reread that section.]

Perhaps such attitudes are lapses from the broader economic and democratic ideals promoted by the U.S. that receive widespread support in the world (Pew Center 2003). But the inconsistent and partial application of those principles causes tension not only with Arab nations, but also European allies and thus both inflame the Arab world and make cooperative action with European allies more difficult. Real and imagined grievances surround both U.S. support for dictatorial Arab regimes and a close strategic 
alliance with Israel, which has a long history of abuses in its intense conflicts with Arab nations. The 'legal black holes' established by the U.S. mostly ensnare Muslims, which furthers the belief that America selectively targets Islam, evidence for some of an enduring Crusader mentality.

The possibility of military tribunals handing down death sentences offended many in Europe as well as the Mid East. Camp X-Ray in the Guantanamo Bay legal black hole holds citizens from several European nations, which have expended great effort to ensure access to diplomatic counsel and promises not to seek the death penalty. Success by European nations and the failure of Arab states to achieve the same furthers the perception of double standards and persecution of Muslims. In addition, the situation creates a strong rift with European states that have all abolished capital punishment, even for war crime and genocide, because it "has no place in the penal system of modern civilized societies" (in Grant 1998: 20). In contrast, the U.S. is steadfast in the face of United Nations criticism of its frequent executions for day to day crimes. America has even executed foreign nationals who had not been notified of the right under the Vienna Convention to contact their embassy for assistance - and one such execution proceeded in violation of a stay ordered by the International Court of Justice (Grant 1998).

More generally, the U.S. demands that other countries extensively revise their laws and legal system to comply with human rights treaties, while it reserves the right to continue executions of juveniles and the mentally retarded. The War on Terror exacerbates existing tensions over capital punishment, which are symbolic of larger skepticism over U.S. moral leadership on human rights and its separatism within an 
international legal order at a time when the emphasis needs to be on democratic actions and international cooperation.

Although criminology can not be responsible for the full range of challenges outlined above, its own shortcomings should be acknowledged before advocating an expansion into new areas. Feagin, in the published version of his American Sociological Association Presidential Address, has a major heading: "Be More Self-Critical" (2001: 13). In the spirit of "accelerated self-reflection" it is important to note that 'crime' is generally limited to "[American] [street] crime." American criminology tends to be about as interested in international and global issues as Americans in general are in international news, with a survey of comparative criminal justice courses concluding "in spite of the rhetoric, not much real progress has been made since the first report on this issue [in 1983]" (quoted in Barberet 2001: 3, bracket provided by Barberet). Michael Tonry concludes that the U.S. is "curiously impervious" to ideas and sentencing innovations from abroad (ibid) and Elliott Currie (1999) describes a problematic "new triumphalism" based on the "American model" of crime reduction.

Americans, including criminologists, do not tend to believe that genocide has happened in the U.S. (Johnson and Leighton 1999; Churchill 1997), so topics related to terrorism - ethnic cleansing, massacres, human rights, etc - are typically not seen as 'relevant.' Thus, homicide is a central topic for criminology, serial killers are trendy, but genocide [from the Greek work genos (race or tribe) and the Latin cide (kill)] is not what 'real' criminology is about (Barak 1998: 39). Even though 'war crimes' has the word 'crime' in it, the topic and related issues like the International Criminal Court are rarely 
discussed in criminology's main journals or conferences. International Law and human rights are likewise marginalized, largely through the impact of political decisions:

The set of [Reservations, Understandings and Declarations] which the Senate has attached to each human rights treaty on ratification has prevented the treaty's provisions from having any direct effect through U.S. courts and from giving individuals justiciable rights. This is one of the principle reasons why international human rights law is so little known, or used, by U.S. lawyers and civil rights advocates and why human rights treaties have remained essentially 'off shore,' and have had little visible impact on U.S. law or practice. (Grant 1998: 26).

The U.S. and other democratic counties thus face the threat of terrorism for the foreseeable future. Besides understanding this violence, key challenges lay in protecting the freedoms that make the U.S. respected round the world and engaging international law in a way that does not undermine our ability to (as the Atomic Scientists put it) pursue 'cooperative international action, legitimized by democracy.' Criminology has some potential to contribute to these pressing problems, but the discipline requires long overdue changes to make it more worldly and intellectually consistent. If September 11 does not prompt change, then it is difficult to imagine what must happen for criminology to stop being parochial or limited by questionable political decisions defining crime and justiciable issues. 


\section{Crime (and Terrorism) in a Free Society (Global Village)}

In order to reveal the wealth of criminological issues raised by terrorism, a new organizing framework or paradigm is useful. It should embrace democracy, be global and not replicate the iatrogenic problems of the War on Crime and Drugs. ${ }^{\text {ii }}$ Going back to a time before the various 'law and order' campaigns, the President's Commission on Law Enforcement and Administration of Justice issued a report entitled, The Challenge of Crime In A Free Society (1967). The Commission disregarded what Packer (1967) calls the President's "embarrassingly naïve" questions (which are not even quoted in the final report) and set off on its own agenda. The Commission included four members from the police and prosecution, but no criminal defense attorneys, and still managed to highlight the importance of freedom: "Our system of justice deliberately sacrifices much in efficiency and even in effectiveness in order to preserve local autonomy and to protect the individual" (1967: 7).

In the next sentence, the Commission states that "sometimes it may seem to sacrifice too much," and noted the limited success in fighting organized crime. One could replace the Commission's reference of "Cosa Nostra-type criminal organizations" with "al Qaida and terrorist networks" and capture current sentiments, just as enemies prior to the Commission (Communism, etc) also created concern about excessive individual rights. However, in reviewing situations going back to Colonial times, former Supreme Court Justice Douglas notes :

"Short cuts are always tempting when one feels his cause is just. Short cuts have always been justified on the grounds that the end being worthy, the means of reaching it are not 
important. Short cuts, however, are dangerous. If they can be taken against one person or group, they can be taken against another. Our greatest struggle has been to provide procedural safeguards that will protect us against ourselves and make as certain as possible that reason and calm judgment will not be swept away by passion and hysteria" (1954: 69).

Overall, Packer (1967) rightly criticizes the Commission's report for avoiding fundamental questions in favor of a public education document awash in "particularism" with recommendations that are "unexpceptional" and "mechanical" ("more money, more people, more research"). Embracing The Challenge of Crime in A Free Society is thus not a call to reread the report, but to recognize the Commission had a productive guiding framework. The ensuing decades focused on 'order' rather than freedom, and the threat of terrorism creates further temptations to sacrifice freedom (even in the name of protecting it). Thus, a new conception should return to embracing freedom, be updated to include terrorism and recognize that technology has made the world so interconnected as to give the globe the feel of a village. Although the entire field of criminology need not take up such questions, criminologists should consider using 9-11, its anniversaries and related events as time for introspection about whether to devote some of the energy to The Challenge of Terrorism for the Free Societies in the Global Village.

For those studying terrorism and related issues, this conception helps to guard against further unnecessary erosions in the democratic freedoms the country is 
ultimately trying to protect. For criminology, this framework has implications both for the subjects within the disciplinary boundaries and for what Quinney has termed "Criminology as Moral Philosophy" (2003). In both cases, the goal is to avoid the type of self-criticism Feagin had for sociology when he noted that in their quest for detached, objective research the major journal in their field from the 1920 to the 1940 s published "remarkably few" pieces on "the growing fascist movements in the United States and Europe, some of which would soon help generate a catastrophic war" (2001: 8-9).

The Challenge of Terrorism for the Free Societies in the Global Village has several important implications for the subject matter of criminology, including its study of violence, criminal procedure, and international law (including human rights). Terrorism builds on the study of violence and hate crimes, which should be supplemented with additional attention to massacres, genocide and mass killings like ethnic cleansing. (These topics, in turn, involve greater exposure to human rights and international law, which are also salient topics in their own right in the global village.) Barak (2003) does an admirable job examining interpersonal, institutional and structural violence, and their relationships across many types of violence; he even manages to connect these to 'pathways to nonviolence' through his reciprocal model. Interestingly, he notes that in response to the terrorists flying suicide missions with airplanes, one enraged man committed a hate crime by driving his car at high speed into a mosque. The behaviors are not identical but highlight the continuity of new research question from ones firmly within the disciplinary boundaries.

Extending current criminological topics like community policing and criminal procedure also open up the discipline to new areas. Someone not familiar with the 
discipline would be unsure if "Community Policing in Battle Garb" (in Kraska 2001: 82) described the task of U.S. soldiers in Iraq trying to do peacekeeping in communities (trying to prevent violence and looting) or the efforts of domestic officers doing community policing in hostile inner cities as part of the war on crime. Indeed, Packer discusses "the war between the police and urban poor," who "see the police more as destroyers than protectors" (1967); contemporary observers comment on police as an 'occupying army' in some neighborhoods. Again, the two are not identical and shaped by different rules of engagement, but greater attention to international laws like the Geneva Convention and International Humanitarian Law helps illustrate the continuity of the criminological issues. More generally, the phenomenon discussed by Kraska, Militarizing the American Criminal Justice System (2001) is a trend that the PATRIOT Act greatly accelerated by blurring criminal justice and national security intelligence gathering. The mixing of functions and expanding police powers are important issues in trying to strike the balance between the threats of terrorism and the threat from Big Brother's surveillance (Reiman 2001). But the blending of criminal justice and military functions also means that a greater range of 'military' and human rights issues are also issues for criminology.

Beyond the implications of the PATRIOT Act, and even war crimes, the 'legal black holes' are important subjects for criminological attention and as signals about the health of democratic freedoms that justice Douglas noted should not be swept away by passion or hysteria. For example, Jose Padilla, accused of plotting to use a radiological ('dirty bomb'), was declared an 'enemy combatant' and taken to a military facility, raising the "pivotal question": "Can an American citizen, arrested on U.S. soil, be held 
incommunicado in a military prison indefinitely -- without being charged with a crime, without access to a lawyer?" (Span 2003: A01). President Bush claims Padilla is not a Prisoner of War or held under the terms of regular criminal procedure - but in either case, the political decision removing Padilla from the criminal justice system does not remove this issue from the scope of criminology.

The last paragraph hints at the second major set of implications, which have to do with the moral and political stance to the topics. Explicit within The Challenge of Terrorism is a concern for democratic freedoms, which in turn is grounded in a conception advanced by Feagin (2001: 6) and Quinney (2003) that the discipline needs to advance the social good and social justice. Quinney conceives of "Criminology as Moral Philosophy" (2003: 355), similar to Postman's view that all social science is moral theology in that it strives "not, obviously, to contribute to our field, but to contribute to human understanding and decency" (1988: 17). Quinney adds the "Criminologist as Witness," by which he means criminology should be a "stance for the witnessing of contemporary history" (2003: 366). Witnessing is not just a passive act but also includes the critique, for example of shortcuts in democratic freedoms, violations of international law (especially when they undermine the potential for international cooperative action), and U.S. refusal to recognize "the political culture of Texas is no less exempt from human rights scrutiny than that of Tehran or Badhdad" (Grant 1998: 29)

The previous paragraphs are meant to be more illustrative than definitive about the impact of a new guiding framework. Although it is not suggested as The Paradigm for all criminology, seeding classrooms with these issues and framework will help students see that criminology is relevant to what's on the nightly national news and not 
just the crime reported on the local evening news. Many of the students will be domestic criminologists or criminal justice practitioners, but criminology can still play a role in preparing them to be citizens of a global village, and hopefully ones who have reverence for democratic freedoms instead of blind patriotism.

\section{The Challenge of Studying Terrorism:}

\section{Anti-Americanism, Anti-Semitism and 'Christian Terrorism'}

Serial killers seem to be chic; they are the object of cultural fascination and attract numerous students to be psychological profilers, like the 'mindhunters' in true crime books and myriad popular media. The passion for learning how to think like a serial killer does not apply to getting inside the head of a terrorist, so there's much more interest in understanding Ted Bundy or even Jack the Ripper than Osama bin Laden. Investigating serial killers tends to be an exercise in abnormal psychology, drawing mostly from individual biography. Understanding terrorism requires confronting the disturbing conclusion that people responsible for mass violence are in many ways normaliii, at least in the sense that people with diagnosable personality disorders tend not to work well in teams or organizations. Indeed, in an extensive literature review, Hudson (1999) concludes that "there is little reliable evidence to support the notion that terrorists in general are psychologically disturbed individuals."

Further, while the motivations of serial killers are personal, terrorism involves political violence, which frequently requires knowledge of politics, world history or international news. More problematically, terrorism related to 9-11 requires an appreciation of intense anti-American sentiments, a topic difficult at the best of times 
and perilous during the outpouring of patriotism following a crisis. While the mind hunters of serial killers get widespread admiration and respect, those trying to understand anti-American terrorism are frequently derided as unpatriotic or worse. For example, one university that simply wanted to require all incoming freshmen to read a book about Islam found itself "besieged in federal court and across the airwaves by Christian evangelists and other conservatives" (Cooperman 2002: A01). Fox News Network's Bill O'Reilly compared the assignment to teaching "Mein Kampf" in 1941 and questioned the purpose of making freshmen study "our enemy's religion" (ibid). [However, one freshman, demonstrating a much better grasp of the issues, commented: "After the terrorist attacks, I was so angry that I really didn't care to learn anything about Muslims. But I know now that refusing to learn is what causes more anger and confusion" (Johnson 2002: A02).]

Many criminologists have critiqued the War on Crime without being anti-police and while maintaining supportive professional relationships with students working in the system, so there should be a basis for critiquing the War on Terror - including military actions - without being 'anti-troop' or unpatriotic. Strong emotions mean the logical argument might be hard to get across, but the author of the book required by the university (previous paragraph) underscored the larger point:

There's a large undercurrent out there that did not believe President Bush when he said Islam is not our enemy. We don't need to condemn those people, or dismiss them. We should talk with them and really talk this thing through, because we're going to be involved in conflicts in areas with 
largely Muslim populations for the foreseeable future (Nightline 2002).

Indeed, the magnitude of the problem with Muslim countries and antiAmericanism is underscored by the Pew Center's Global Attitudes Survey, which asked people in different countries about their confidence in different leaders to "do the right thing regarding world affairs" (2003). Osama bin Laden came out ahead of President Bush in several countries whose combined population approaches a half billion people (see Table 1). This survey, done after 9-11, is consistent with earlier information that "scores of Pakistanis have named their newborn sons Osama," highlighting that the terrorists may be on the fringe "but those who applaud are the disenfranchised Muslims everywhere" (Reeve 1999: 203).

TABLE 1: Percent of People Expressing Confidence in Bush or Osama bin Laden to "do the right thing regarding world affairs"

\begin{tabular}{|l|l|l|l|}
\hline COUNTRY & BUSH & BIN LADEN & 2003 POPULATION \\
\hline Indonesia & 8 & 58 & 234.89 million \\
\hline Jordan & 1 & 55 & 5.46 \\
\hline Morocco & 2 & 49 & 31.69 \\
\hline Pakistan & 5 & 35 & 150.7 \\
\hline $\begin{array}{l}\text { Palestinian } \\
\text { Authority }\end{array}$ & 1 & 71 & 3.3 \\
\hline Turkey & 8 & 15 & 68.11 \\
\hline & & & 494.15 million \\
\hline
\end{tabular}


Indicates percent expressing "A lot" or "some" confidence. Source: Pew Global Attitudes Survey (2003), Topline Results p 154-155, 158. Population Data from U.S. Census, International Data Base, available: http://www.census.gov/ipc/www/idbsum.html. Data for Palestinian Authority for 2001, from Jewish Virtual Library, American Israeli Cooperative Enterprise. Available: http://www.us-israel.org/jsource/arabs/palpop01.html

Some of the foreign policy issues underlying anti-Americanism are beyond criminology, but the 'terrorist as hero' motif builds on Criminals as Heroes (Kooistra 1989), which examines the celebrity status accorded wild west outlaws and $20^{\text {th }}$ Century gangsters. Hero status occurs when an audience finds "some symbolic meaning in his criminality" (1989:152), for example when substantial segments of the public feel '"outside the law' because the law is no longer seen as an instrument of justice but as a tool of oppression wielded by favored interests" (1989:11). At such times, or among groups with this perception, there is a 'market' for symbolic representations of justice and "a steady need for the production of celebrities" (Kooistra 1989:162). (This analysis indicates an issue going beyond individual terrorists and suggests that disenfranchisement is a more fruitful avenue than the more simplistic question of whether poverty causes terrorism.)

Although anti-Americanism is an important issue, there are also significant limitations on its ability to explain terrorist attacks perhaps directed at Western targets but that kill large numbers of Arabs and fellow Muslims. Hoagland notes: "Events since [9-11] have shown that [why do they hate us?] was too self-centered and exclusionary a reflex. Those who hate in this way hate much more than us" (2003: B07). Their project is ultimately much larger than anti-Americanism because "the radicals have an entire world to destroy before their apocalyptic design of restoring the Islamic caliphate can be 
realized" (ibid). The caliph is "an integral part of Islam's glory," a "divinely mandated leader whose forces led a lightning conquest of much of the known world for the faith" (Benjamin and Simon 2002: 47). Restoring the caliphate is a reference to the dream of a multi-nation Islamic superpower ruled under sharia or Islamic law.

Making sense of this part of bin Laden's quest involves an examination of the influence of medieval Muslim theologian ibn Taymiyya. In contrast to the religiousscholarly establishment of the time, he believed in a personal engagement with holy writ and is thus akin Martin Luther (Benjamin and Simon 2002: 46). Issues of statecraft and governance were central to ibn Taymiyya's writings, especially the secularization of government and the consequent subordination of religion to the state. Rulers needed to enforce sharia and exhibit personal piety: "To obey a leader who violated the percepts of Islam would be to reject the word of God and be guilty of apostasy oneself" (Benjamin and Simon 2002: 48). Ibn Taymiyya wanted to purify Islam and a crucial aspect of this task was jihad, holy war - and not the 'inner' jihad or individual struggle to become more devout. Jihad was against enemies, but not just the ones at the political borders: "By asserting that jihad against apostates within the realm of Islam is justified - by turning jihad inward and reforging it into a weapon for use against Muslims as well as infidels he planted a seed of revolutionary violence in the heart of Islamic thought" (Benjamin and Simon 2002: 50).

In a rich and readable chapter, Benjamin and Simon trace this current of thought from ibn Taymiyya through the Crusades, the humiliating rise of European ascendancy, down to bin Laden. Along the way are figures like prison author Sayyid Qutb, who "for better or worse, is the Islamic world's answer to Solzhenitsyn, Sartre and Havel, and he 
easily ranks with all of them in influence" (2002: 62). He saw "virtually every confrontation between the worlds of Islam and the West [as] a repetition" of the Crusades, which are "an ancient and perpetual antagonism, unconfined by specifics of time and place" (ibid, 66).

The many strains of thought converge in bin Laden, who asserts his own right to interpret religious doctrine and views less militant interpretations as coming from the paid lackeys of apostate leaders bought off by the U.S. Indeed, such governments tend to be more Western, secular and thus not only place human judgment over the divine but lead Muslims away from the true faith. For bin Laden, the overthrow of such governments is an important step to securing rule by those such as the Taliban, who govern in accordance with Islamic law. The ultimate goal, however, is to create an Islamic superpower and resurrect the glory days where Islam was a powerful force, united under a divinely appointed ruler. To this end, bin Laden has released a fatwa (religious decree, even though technically he does not possess the authority) about the "Zionist-Crusader Alliance" and elsewhere has indicated that acquiring a nuclear weapon is a religious duty (Benjamin and Simon 2002: 140, 160).

Bin Laden's fatwa highlights the importance of anti-Semitism and antiAmericanism; it also connects al Qaida with domestic terrorists reading the Turner Diaries (MacDonald 1978) and identifying with the characters' struggle against Z.O.G., the Zionist Occupied Government. Israel is viewed with hostility in much of the Arab world because of its treatment of Arabs, especially Palestinians. In addition to being a close ally of Israel, the U.S. is also perceived to mistreat Arabs and have double standards for enforcing human rights, especially when it comes to Israel. Within the 
U.S., many on the survivalist right see Israel as dominating the United Nations, the 'New World Order' and/or the U.S. government, with mass media ("Jewsmedia" rather than "newsmedia") being the propaganda arm of ZOG (Ridgeway 1995; Ezekiel 1995; MacDonald 1978). Among those on the survivalist right who see the U.S. government as having lost legitimacy, the strikes on the Pentagon, World Trade Center and a heavily Jewish town like New York City were not cause for anger or patriotism, but respect at a successor to McVeigh (Hamm 1997). (Remember that the FBI still does not know if the anthrax attacks on the media and Congress were from al Qaida or a domestic terrorist with is own anti-government agenda.)

Aside from concerns about U.S. and foreign terrorists working together, the larger point is not to get so focused on al Qaida as to forget about domestic threats. Russell argues that black men and crime are so closely linked and so strongly embody white America's fear of crime as to warrant using "criminalblackman" (1998). This focus on street crime, especially by racial minorities, helps deflect attention from a great deal of white collar and corporate crime (Enron, etc) that is far more harmful (Reiman 2004). "Islamicterrorist" should not blind people to the threats of domestic terrorism or the value in studying it. Further, imagine calling someone like Randolph, the Atlanta Olympic bomber, a "Christian terrorist" because he declared "total war on the ungodly communist regime in New York and your legislative [sic] bureaucratic lackey's in Washington. It is you who are responsible and preside over the murder of children and issue the policy of ungodly 
preversion thats [sic] destroying our people" (in Cooperman 2003: A03).

As Aho notes, most mainstream Christians would consider Randolph's version of Christianity ('Christian Identity') to be a heresy: "If Christians take umbrage at the juxtaposition of the words 'Christian' and 'terrorist,' he added, 'that may give them some idea of how Muslims feel' when they constantly hear the term 'Islamic terrorism,' (in Cooperman 2003: A03; see also Aho 1990).

Further, most people assumed the perpetrator of the federal building in Oklahoma City attacked was Middle Eastern, yet it turned out to be McVeigh. When the World Trade Centers and Pentagon were hit, people again assumed the perpetrator was Arab. This time, they were right, but The Turner Diaries (MacDonald 1978) ends with a nuclear suicide mission into the Pentagon; the "great Houston bombings" occur in the novel on September 11, "which left more than 4,000 persons dead and much of Houston's industrial and shipping facilities smoldering wreckage" (MacDonald 1978: 94). Additional commonalities in the thinking of domestic and international terrorist include Earl Turner's fictional group The Order favoring multiple simultaneous attacks (MacDonald 1978: 62), much like al Qaida.

Bin Laden believes that if he can weaken the U.S. economically, it will not have resources to enslave others (Benjamin and Simon 2002: 156). The Order starts out by trying to cause trouble so that the government will become repressive and people will rise in revolt. However, the Order realizes that people will not revolt as long as they have a paycheck, color TV and a full belly (1978: 101) - so the emphasis shifts to undermining infrastructure: 
power stations, fuel depots, transportation facilities, food sources, key industrial plants. We do not expect to bring down the already creaky American economic structure immediately, but we do expect to cause a number of localized and temporary breakdowns, which will gradually have a cumulative effect on the whole public (1978: 102).

Other ideas involve counterfeiting, hitting a nuclear reactor and finally stealing nuclear missiles. By the novel's end, The Order launches nuclear weapons, killing millions and causing genocide in an effort to 'liberate' first the U.S., then the planet: "we will liquidate all the enemies of our people, including in particular all white persons who have consciously aided those enemies" (1978: 181; see also discussion of 'slaughter of innocents,' p 195 ff). Substituting 'Islam' for the 'White Race' that Turner fights for would reveal a proximate outline of bin Laden's 'apocalyptic design of restoring the Islamic caliphate' that might claim large numbers of Muslim lives. Believers in either are dangerous and similar in at least some important ways.

\section{Conclusion}

Realizing that an unknown number of people harbor fantasies of mass nuclear annihilation is disturbing - even more so when one considers the popularity of bin Laden or the Turner Diaries. There's a temptation to find topics that don't keep one up at night and that make better polite conversation when people ask about what you study. Criminology journals are likely to remain receptive to unimaginative and marginally relevant but technically well executed quantitative pieces over an extended 
treatment of issues raised in this chapter. While not all criminologists should take up these topics, more should - and professional introspection should be widely encouraged.

Researchers who investigate genocide note that they risk displacing economics as 'the dismal science,' and studying terrorism is a step in that same direction. But there are also risks in not moving in that direction, of rearranging deck chairs (or regression models of deck chair theft) and neglecting the big threats. Friedrichs, "as someone who has co-taught a course on the Holocaust for quite a number of years" had "long wondered what German criminologists were doing in the 1930s, while their state was in the process of implementing one of the great crimes in human history" (2002). Obviously they were not addressing Nazism and he asks, "What the Hell were they thinking?"iv Many continued to study conventional forms of criminal behavior, which some imbued with the racist, biogenic approach of the government. While not trying to compare the U.S. to the Nazis, the point is to ask about the judgment of history at an important juncture: will future generations ask of criminology, "What were they thinking?" 


\section{References}

Aho, James. 1990. The Politics of Righteousness. Seattle: University of Washington Press.

Anderson, Curt. 2003. "FBI planning offices in foreign capitals." Available, http://www.onlineathens.com/stories/032903/war 20030329104.shtml (Accessed 28 June 2003).

Arendt, Hannah. Eichmann in Jerusalem: A Report on the Banality of Evil, revised and enlarged edition. New York: Viking Press 1963, 1964.

Atomic Scientists. 2002. "From the Board of Directors: It's Seven Minutes to Midnight." Bulletin of the Atomic Scientists, 27 February.

Barak, Gregg. 2003. Violence and Nonviolence. Thousand Oaks: Sage. 1998. Integrating Criminologies. Boston: Allyn and Bacon.

Barberet, Rosemary. 2001. "Global Competence and American Criminology - An Expatriate's View" The Criminologist, v 26 \#2 (March/April).

Benjamin, Daniel and Steven Simon. 2002. The Age of Sacred terror. New York: Random House.

Blumstein, Alfred and Joel Wallman (eds). 2000. The Crime Drop in America. Cambridge: Cambridge University Press.

Churchill, Ward. 1997. A Little Matter of Genocide. San Francisco: City Lights Books.

CNN. 2003. Al-Jazeera airs purported bin Laden tape. September 10. Available, http://www.cnn.com/2003/WORLD/meast/09/10/binladen.tape/

Clear, Todd. 2002. “The Problem with 'Addition by Subtraction': The Prison-Crime Relationship in Low-Income Communities" in Mark Mauer and Meda Chesney- 
Lind (eds), Invisible Punishment: The Collateral Consequences of Mass Imprisonment. New York: The New Press.

Cooperman, Alan. 2003. Is Terrorism Tied To Christian Sect?: Religion May Have Motivated Bombing Suspect. Washington Post, 2 June. 2002. A Timely Subject -- and a Sore One: UNC Draws Fire, Lawsuit for Assigning Book on Islam. Washington Post, August 7.

Currie, Elliott. 1999. "Reflections on Crime and Criminology at the Millenium." Western Criminology Review 2(1). [Online]. Available: http://wcr.sonoma.edu/v2n1/currie.html.

Douglas, William. 1954. An Almanac of Liberty. Garden City (N.Y.): Doubleday \& Co. Ezekiel, Raphael. 1995. The Racist Mind. New York: Viking/Penguin.

Feagin, Joe. 2001. "Social Justice and Sociology: Agendas for the Twenty-First Century" American Sociological Review, v 66: 1-20.

Federal Bureau of Investigation. 2002a. Crime in the United States, 2001. Washington, D.C.: Government Printing Office. 2002b. Crime Trends, 2001 Preliminary Figures. Available, http://www.fbi.gov/ucr/01prelim.pdf. 1996. Crime in the United States, 1995. Washington, D.C.: Government Printing Office.

Friedrichs, Dave. 2002. September $11^{\text {th }}$ And Its Aftermath. In Mark Hamm and Paul Leighton, Teaching and Understanding September 11. Available: http://stopviolence.com. 
Grant, Stephanie. 1998. "A Dialogue of the Deaf? New International Attitudes and the Death Penalty in America" Criminal Justice Ethics, v 17 \#2.

Hamm, Mark. 1997. Apocalypse in Oklahoma. Boston: Northeastern University Press. Hoagland, Jim. 2003. Fighting for the Soul of Islam. Washington Post, 13 July, p B07 Hudson, Rex. 1999. The Sociology and Psychology of Terrorism: Who Becomes A Terrorist and Why? Washington, D.C. Federal Research Division, Library of Congress and U.S. Dept of Commerce, National Technical Information Service. (A short excerpt bearing directly on the question of mental illness is available through http://stopviolence.com > Sept 11 Contents.)

Johnson, Robert. 2003. "Village Life." Poem available in Sept. 11 section of http://stopviolence.com.

Johnson, Robert and Paul Leighton. 1999. "American genocide: The Destruction of the Black Underclass" in Craig Summers and Eric Markusen (eds) Collective Violence: Harmful Behavior in Groups and Governments Lanham: Rowman \& Littlefield. (A shorter version of this article is available through http://paulsjusticepage.com.)

Johnson, Doug. 2002. N.C. University Students Discuss Readings in Islam: Christian Group Sought to Bar Assignment on Koran. Washington Post, August 20.

Kittrie, Nicholas and Eldon Wedlock (eds). 1998. The Tree of Liberty: A Documentary History of Rebellion and Political Crime in America. Volume 2: Cold War to New World Order (revised ed). Baltimore: Johns Hopkins University Press.

Kooistra, Paul. 1989. Criminals As Heroes: Structure, Power and Identity. Bowling Green: Bowling Green State University Popular Press. 
Kraska, Peter. 2001. Militarizing the American Criminal Justice System. Boston: Northeastern University Press.

Kutz, Howard. 2002. "Despite Sept 11, Interest Still Low in Foreign News." Washington Post, June 10, p A13.

MacDonald, Andrew. 1980. The Turner Diaries, $2^{\text {nd }}$ ed. New York: Barricade Books.

McLaughlin, Abraham. 2002. "How Far Americans would go to fight terror." Christian Science Monitor, November 14. Available, http://www.csmonitor.com/2001/1114/p1s3-usju.html.

Milbank, Dana and Mike Allen. 2003. "Security May Not Be Safe Issue for Bush in '04" Washington Post. August 22.

Nightline. 2002. Koran Dispute: Students Discuss Islamic Holy Book Analysis After a Court Fight to Block It. August 25. Available: http://abcnews.go.com/sections/nightline/DailyNews/koran020824.html.

Packer, Herbert. 1967. "Copping Out" New York Review of Books, v 9 \#6 (12 October). Pew Center. 2003. "View of A Changing World". Washington D.C.: The Pew Research Center for The People and The Press. Available: http://peoplepress.org/reports/display.php3?ReportID=185.

Postman, Neil. 1988. "Social Science As Moral theology" in Contentious Objections. New York: Vintage/Random House.

President's Commission on Law Enforcement and Administration of Justice. 1967. The Challenge of Crime In A Free Society. Washington, D.C.: U.S. Government Printing Office. 
Quinney, Richard. 2003. "Criminology as Moral Philosophy, Criminologist as Witness. In Darnell Hawkins, Samuel Myers and Randolph Stone (eds) Crime Control and Social Justice. Westport: Greenwood.

Reeve, Simon. The New Jackals: Ramzi Yousef, Osama bin Laden and the Future of Terrorism. Boston: Northeastern University Press.

Reiman, Jeffrey. 2004. The Rich Get Richer and the Poor get Prison, $7^{\text {th }}$ ed. Boston: Allyn \& Bacon.

. 2001. "Driving to the Panopticon: A Philosophical Exploration of the Risks to Privacy Posed by the Highway Technology of the Future" in Paul Leighton and Jeffrey Reiman (eds), Criminal Justice Ethics. Upper Saddle River: Prentice-Hall. Ridgeway, James. 1995. Blood in the Face: The Ku Klux Klan, Aryan Nations, Nazi Skinheads, and the Rise of a New White Culture, $2^{\text {nd }}$ ed. New York: Thunder's Mouth.

Rosenfeld, Richard. 2002. Why Criminologists Should Study Terrorism. The Criminologist: The Official Newsletter of the American Society of Criminology. V 27 \#6 (November/December).

Russell, Katheryn K. 1998. The Color of Crime: Racial Hoaxes, White Fear, Black Protectionism, Police Harrassment, and other Macroaggressions. New York: New York University Press.

Span, Paula. 2003. Enemy Combatant Vanishes Into a 'Legal Black Hole'. Washington Post, July 30. 
Leighton, Challenge of Terrorism, p 32 of 34. See http://stopviolence.com > Sept 11 contents 


\section{ENDNOTES:}

'Elsewhere, I have created an extensive web page that discusses the string of terrorism attributed to Al Qaida, as well as links discussing the group's intensive efforts to acquire Weapons of Mass Destruction. This page is part of Mark Hamm and Paul Leighton (ed), Teaching and Understanding Sept 11, the full contents of which are freely available through http://stopviolence.com > Sept 11 contents. For the bin Laden page, check in the 'Photo' section of the main table of contents. Other sections include syllabi and writings on: terrorism and political violence; Mid East, Islam and anti-Americanism; and Law and International Justice. This project is part of an effort to think in a new way and is explained in the original (2002) full introduction, available from the main contents page.

${ }^{\text {ii }}$ Iatrogenic is a medical term related to injury or illness that result from medical treatment, such as getting an infection from an operation. Within the drug war, the harm reduction approach blames current policies for infections and HIV because clean needle exchanges are not legal; one effect of mass incarceration is to weaken informal social controls like family and community (Clear 2002). President Bush went into Iraq supposedly to prevent terrorism, but at this point the chaotic situation may be a breeding ground for terrorism and anti-Americanism.

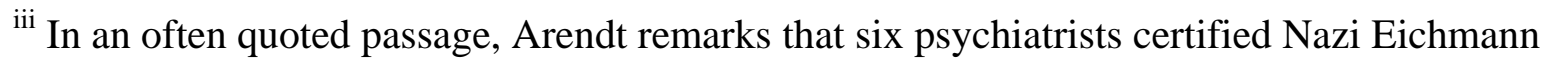

“as 'normal'--'More normal, at any rate, than I am after having examined him,' one of them is said to have exclaimed, while another had found that his whole psychological outlook, his attitude toward his wife and children, mother and father, brothers, sisters, and friends, was 'not only normal but most desirable'”(1964: 25-26).

${ }^{\text {iv }}$ He used this more pointed language in a discussion we had at the first American Society of Criminology meeting after 9-11. 